\title{
Effect of Salicylic Acid on Physico-chemical Attributes and Shelf Life of Tomato Fruits at Refrigerated Storage
}

\author{
Debashis Mandal*, Lalhlimpuii Pautu, Tridip Kumar Hazarika, Bhagwati Prasad Nautiyal and Amritesh Chandra Shukla \\ Department of Horticulture, Aromatic and Medicinal Plants, Mizoram University, Aizawl, Mizoram (796 004), India
}

\section{Article History}

Manuscript No. AR1683b

Received in $8^{\text {th }}$ September, 2016

Received in revised form $16^{\text {th }}$ November, 2016

Accepted in final form $30^{\text {th }}$ November, 2016

\section{Correspondence to}

${ }^{*} E$-mail: debashismandal1982@gmail.com

\section{Keywords}

Refrigerated storage, salicylic acid, chilling injury, lycopene, shelf life, tomato

\begin{abstract}
Tomato, the frequently consumed solanecous fruit vegetable faced rapid deterioration of fruit edible quality under ambient storage and though refrigerated storage has proved better retention but mostly with the outbreak of chilling injury. Therefore, attempt with salicylic acid, a safe phenolic having identified anti-ethylene effect, has been made during this study to evaluate its effect on shelf life and quality attributes of tomato fruit in refrigerated storage. Fruits of tomato variety Samrudhi at pink to light red stage were treated with different concentration of salicylic acid $(0.2-1.2 \mathrm{mM})$ along with control (water dipped) and were kept at $4-5{ }^{\circ} \mathrm{C}$ with $65-80 \%$ relative humidity in four replications following complete randomized design. Results showed salicylic acid (SA) treated fruits had better keeping quality than control though in concentration dependant manner. At 21 days after storage (DAS), fruits kept in control condition lost $13.69 \%$ of weight compared with the fruits treated with SA at $1.2 \mathrm{mM}(5.79 \%)$. SA at 1-1.2 mM significantly reduced chilling injury (Chilling Injury Index/CII: 1.44-2.88) compared with fruits at control (CII: 4.98). Fruits at control showed deterioration in sugar content along with acidity and ascorbic acid. Further, it took rapid increase in pigment whereas, SA treated fruit in relatively higher concentration $(0.8-1.2 \mathrm{mM})$, maintained fruit quality attributes with consistent intensification of carotenoids and lycopene even at $21 \mathrm{DAS}$. SA at $1.2 \mathrm{mM}$ recorded maximum shelf life (32.75 days) to be considered as the best treatment having high maintenance of fruit edible qualities.
\end{abstract}

\section{Introduction}

Tomato is an important warm season fruit vegetable grown throughout the world and occupying significant position in Indian vegetable production (Gopalakrishnan, 2007). Tomato belongs to the family Solanaceae, genus Lycopersicon and sub family Solanoidae. Tomato fruits are rich source of minerals like calcium, sodium, copper and other trace elements, vitamins like vitamin A (900 IU), vitamin C (27 mg), vitamin B complex along with organic acids like citric, formic and acetic acid and essential amino acids for which tomato occupies a important position in the list of protective foods (Gopalakrishnan, 2007). Tomato is known to have an anti-cancer property due to presence of the red colour pigment lycopene (Rao and Agarwal, 1999). India is the $2^{\text {nd }}$ highest producer of tomato ( 182.26 lakh MT) next to China (Anon., 2014a). Tomato is exported mainly to the countries like Pakistan, UAE, Bangladesh, Nepal, Saudi Arabia, Oman, Maldives, Bahrain, Russia and Malawi from India and the fresh export of tomato is 3.44 lakh t worth 55305 lakhs, which is quite less (Anonymous, 2014b).
Tomato is regarded as the most common and frequently used fruit vegetable which always having a good market demand. However, it encounters several problems in the transportation, storage and marketing since it is highly perishable (Pila et al., 2010). Due to this, it has been resulted in the loss during harvesting, transportation and consumption of fresh tomatoes and which accounts to $20-25 \%$ loss in tropical countries (Aworth and Olorunda, 1981). Apart from loss caused through transport and marketing; cold storage, perhaps enhanced shelf life, however, with chilling injury. Salicylic acid is reported as a natural and safe phenolic compound which has been found to generate a wide range of metabolic and physiological responses in plants and act as potential bio agent in controlling post harvest loss of horticultural crops and delay in ripening through inhibition of ethylene biosynthesis or action (Asghari and Aghdam, 2010). Salicylic acid has potential reports for alleviating chilling injury in sweet orange (Ahmad et al., 2013) and strawberry (Babalar et al., 2007) and extending shelf life by maintaining physico-chemical attributes both in cold or at ambient storage (Barman and Asrey, 2014; Mandal et al., 
2016). Therefore, the present investigation was taken up to study the effect of salicylic acid in a view to extend shelf life and maintain the quality of tomato.

\section{Materials and Methods}

\subsection{Location of experiment}

The experiment was carried out during May-June, 2015, at Research Laboratory, Department of Horticulture, Aromatic \& Medicinal Plants, Mizoram University; with freshly harvested fruits of tomato cv. Samrudhi $\left(F_{1}\right.$ Hybrid from East-West Seed International Ltd., Thailand) obtained from a local tomato grower of Durtlang village, Aizawl district of Mizoram. Fruits cultivated under green house condition were selected as samples with specific maturity indices i.e. pink to light red stage.

\subsection{Treatments}

Seven post-harvest treatments viz. fruit dipping in Salicylic Acid (SA) at $0.2 \mathrm{mM} \mathrm{l}^{-1}, 0.4 \mathrm{mM} \mathrm{l}^{-1}, 0.6 \mathrm{mM} \mathrm{l}^{-1}, 0.8 \mathrm{mM} \mathrm{l}^{-1}$, $1.0 \mathrm{mM} \mathrm{l}^{-1}, 1.2 \mathrm{mM} \mathrm{l}^{-1}$ and control (treated with water: $\mathrm{T}_{7}$ ) with four replications were used and statistical analysis was done by following complete randomized design (Gomez and Gomez, 1984). Salicylic Acid of respective concentrations was prepared by diluting in warm distilled water and cooled down before dipping of fruit for 5 minutes whereas fruit samples dipped in distilled water for 5 minutes were taken as control. The entire experiment was conducted at refrigerated condition $\left(4-5{ }^{\circ} \mathrm{C}\right.$ with $65-80 \%$ relative humidity).

\subsection{Determination of weight loss}

Fruits for each treatment were tagged and weighed at 7 days interval using a digital electronic balance. The percentage weight loss was calculated by the following equation:-

Percentage weight loss at $\mathrm{n}^{\text {th }} \mathrm{day}=\frac{\mathrm{wt} \text {. loss }\left(0 \text { day- } \mathrm{n}^{\text {th }} \text { day }\right)}{\text { Wt. at } 0 \text { day }} \times 100$
2.4. Biochemical parameters

The fruits were prepared for analysis by cutting and macerating the flesh with mortar and pestle and strained with clean muslin cloth. Analyses were carried out immediately for total soluble solids (TSS), total sugar, reducing sugar, titratable acidity, TSS: acid ratio and ascorbic acid content.

\subsubsection{Determination of total soluble solids (TSS)}

The total soluble solids of the fruits were determined with the help of hand refractometer calibrated in ${ }^{\circ} \mathrm{Brix}$ at $20^{\circ} \mathrm{C}$ with necessary correction factor.

\subsubsection{Determination of total sugar and reducing sugar}

The total sugar and reducing sugar content of fruit juice were estimated by standard procedure of A.O.A.C. (1990) using Fehling's A and Fehling's B reagents with methylene blue as an indicator through copper reduction method.

\subsubsection{Determination of titratable acidity}

Total titrable acidity was determined by titrating the extracted juice against $\mathrm{N} / 10 \mathrm{NaOH}$ (sodium hydroxide) using phenolphthalein as indicator and expressed in percentage (A.O.A.C., 1990).

\subsubsection{Determination of TSS/acid ratio}

The ratio for fruit juice under each treatment was calculated by dividing TSS value by titratable acidity content of fruit.

\subsubsection{Determination of ascorbic acid}

2, 6 dichlorophenol indophenols dye titration method was used to estimate the ascorbic acid content of fruit (A.O.A.C., 1990; Ranganna, 1977) and expressed as mg $100 \mathrm{~g}^{-1}$ of fruit.

\subsection{Determination of lycopene}

Determination of lycopene was performed by using acetone, petroleum ether and anhydrous sodium sulphate following the procedure described by Ranganna (1977). Absorbance was measured using a Digital Spectrophotometer at $503 \mathrm{~nm}$. Final value of lycopene content was converted into $\mu \mathrm{g} \mathrm{g}^{-1}$ unit.

\subsection{Determination of carotenoids}

Carotene content of the fruit was determined by using acetone, hexane and magnesium carbonate following the standard procedure given by Sadasivam and Manickam (1997). Determination was done by calculating carotene (mg $\left.100 \mathrm{~g} \mathrm{~g}^{-1}\right)$ in the sample using standard curve prepared with different concentration of $\beta$-carotene standard and measuring absorbance at $436 \mathrm{~nm}$ wave length using a digital spectrophotometer. Final value of carotene content was converted into $\mu \mathrm{g} \mathrm{g}^{-1}$ unit.

\subsection{Chilling injury index (CII)}

Chilling injury index based on external damage was scored on each fruit using a subjective scale: $=$ no damage, $2=$ slight damage, $3=$ medium damage, $4=$ severe damage, $5=$ very severe damage. The CII was calculated on 21 days after storage (DAS) according to the formula used by Mohammed and Wickham (1996).

CI index $=\Sigma \Sigma_{0}^{5} \frac{(\text { Injury level }) \times(\text { No. of fruits at this level })}{\text { Total no. of fruits }}$

\subsection{Shelf life of fruit}

Optimum shelf life (days) of fruit under different treatment in refrigerated condition were evaluated depending on the visual observation of chilling injury, fruit physico-chemical parameters and counting the days from harvest to the day with maximum edible and marketable quality (Pila et al., 2010; Moneruzzaman et al., 2009; Mandal et al., 2015) .

\section{Results and Discussion}

\subsection{Physiological weight loss}

Present study manifested that tomato fruit significantly lost its physiological weight during storage at refrigerated condition 
in all the treatments. Generally the weight loss of tomato fruits increased progressively during their storage (Pila et al., 2010). Znidarcic and Pozrol (2006) also reported about loss of physiological weight of tomato even in storage under low temperature of $5-10{ }^{\circ} \mathrm{C}$. Result of the present investigation indicated that tomato fruit which were not treated with SA showed considerably high percentage of weight loss (6.64\%) after 14 days of storage in refrigerated condition (Table 1). At 21 DAS, it was the fruit at control which got maximum loss in physiological weight (13.69\%). Okolie and Sanni (2012) reported that fruits at control had maximum weight loss $(6.87 \pm 0.01 \%)$ at 14 DAS of cold storage. Gharezi et al. (2012) opined that weight loss of fresh tomatoes is primarily due to transpiration and respiration. Transpiration is a mechanism

Table 1: Effect of selected post-harvest treatments on percentage weight loss, chilling injury index and shelf life of tomato fruits under refrigerated storage

\begin{tabular}{|c|c|c|c|c|c|}
\hline \multirow[t]{2}{*}{ Treatments } & \multicolumn{3}{|c|}{ PW } & \multirow{2}{*}{$\begin{array}{c}\text { CII } \\
21 \\
\text { DAS }\end{array}$} & \multirow{2}{*}{$\begin{array}{c}\text { Shelf } \\
\text { life } \\
\text { (days) }\end{array}$} \\
\hline & $\begin{array}{c}7 \\
\text { DAS }\end{array}$ & $\begin{array}{c}14 \\
\text { DAS }\end{array}$ & $\begin{array}{c}21 \\
\text { DAS }\end{array}$ & & \\
\hline SA at $0.2 \mathrm{mM}$ & 4.03 & 5.95 & 8.93 & 4.80 & 25.25 \\
\hline $\mathrm{SA}$ at $0.2 \mathrm{mM}$ & 3.84 & 5.82 & 8.61 & 4.32 & 26.75 \\
\hline $\mathrm{SA}$ at $0.4 \mathrm{mM}$ & 3.78 & 5.67 & 7.24 & 3.60 & 27.50 \\
\hline $\mathrm{SA}$ at $0.6 \mathrm{mM}$ & 3.05 & 4.67 & 6.31 & 3.60 & 28.75 \\
\hline SA at $0.8 \mathrm{mM}$ & 2.92 & 4.59 & 6.07 & 2.88 & 30.75 \\
\hline $\mathrm{SA}$ at $1.0 \mathrm{mM}$ & 2.75 & 3.72 & 5.79 & 1.44 & 32.75 \\
\hline $\mathrm{SA}$ at $1.2 \mathrm{mM}$ & 5.24 & 6.64 & 13.69 & 4.98 & 24.00 \\
\hline Control & 0.2794 & 0.2886 & 0.4714 & - & 0.9177 \\
\hline $\begin{array}{l}\mathrm{CD} \text { at } \\
(p=0.05)\end{array}$ & 0.8218 & 0.8491 & 1.3867 & - & 2.6996 \\
\hline
\end{tabular}

PW: Percentage of weight loss (\%); CII: Chilling injury index in which water is lost due to differences in vapour pressure of water in the atmosphere and the transpiring surface. Respiration causes a weight reduction because a carbon atom is lost from the fruit each time a carbon dioxide molecule is produced from an absorbed oxygen molecule and evolved into atmosphere (Bhowmik and Pan, 1992). It was seen that SA treated fruits had significantly less percentage of weight loss during storage. At $21 \mathrm{DAS}, \mathrm{SA}$ at $1.2 \mathrm{mM}$ caused minimum weight loss $(5.79 \%)$ followed by the fruits treated with SA at $1.0 \mathrm{mM}(6.07 \%)$. Tareen et al. (2012) reported that Kiwi fruits treated with SA at $0.2 \mathrm{mM}$ showed lowest loss of fruit weight. SA has been reported to close stomata which results in suppressed respiration rate and minimize weight loss of fruits (Manthe et al., 1992; Zheng and Zhang, 2004). Kamal Kant et al. (2013) reported that exogenous application of SA reduced weight loss of tomato fruits.

\subsection{TSS, titrable acidity and TSS:acid ratio}

Present study revealed that tomato fruits stored at refrigerated condition had gradual increase in TSS value with decreasing titrable acidity which inturn increased TSS: acid ratio at the end of 21 days storage (Table 2). Gharezi et al. (2012) had similar kind of observation in cold storage of cherry tomato, where TSS value increased upto 10 DAS afterward declined along with decrease in fruit titrable acidity. They reported that fruits at control had $4.5 \%$ TSS at 0 DAS, which increased to $4.6 \%$ at 10 DAS and declined to $4.5 \%$ TSS finally at 15 DAS at cold storage, whereas, titrable acidity was $0.4 \%$ at 0 DAS which become $0.35 \%$ at 15 DAS. In the present study it was found that fruits at control showed $4.72{ }^{\circ}$ Brix TSS at 7 DAS which increased to $6.08^{\circ} \mathrm{Brix}$ at $14 \mathrm{DAS}$ and finally declined to $4.82{ }^{\circ} \mathrm{Brix}$ at $21 \mathrm{DAS}$, whereas titrable acidity was $0.26 \%$ at 7 DAS which ultimately reduced to $0.13 \%$ at 21 DAS.

Fruits treated with SA at $1-1.2 \mathrm{mM}$ showed delayed increase

Table 2: Effect of selected post-harvest treatments on total soluble solids (TSS), titrable acidity and TSS: acid ratio of tomato fruits under refrigerated storage

\begin{tabular}{|c|c|c|c|c|c|c|c|c|c|}
\hline \multirow[t]{2}{*}{ Treatments } & \multicolumn{3}{|c|}{ TSS ( ${ }^{\circ}$ Brix $)$} & \multicolumn{3}{|c|}{ Titrable acidity $(\%)$} & \multicolumn{3}{|c|}{ TSS: Acid ratio } \\
\hline & $7 \mathrm{DAS}$ & 14 DAS & $21 \mathrm{DAS}$ & $7 \mathrm{DAS}$ & 14 DAS & $21 \mathrm{DAS}$ & $7 \mathrm{DAS}$ & 14 DAS & $21 \mathrm{DAS}$ \\
\hline SA at $0.2 \mathrm{mM}$ & 4.44 & 5.92 & 4.92 & 0.32 & 0.24 & 0.19 & 13.88 & 24.67 & 25.89 \\
\hline SA at $0.2 \mathrm{mM}$ & 4.42 & 5.82 & 4.96 & 0.32 & 0.26 & 0.19 & 13.81 & 22.38 & 26.11 \\
\hline SA at $0.4 \mathrm{mM}$ & 4.28 & 5.18 & 5.04 & 0.38 & 0.32 & 0.22 & 11.26 & 16.19 & 22.91 \\
\hline SA at $0.6 \mathrm{mM}$ & 4.12 & 4.60 & 5.16 & 0.42 & 0.32 & 0.26 & 9.81 & 14.38 & 19.85 \\
\hline $\mathrm{SA}$ at $0.8 \mathrm{mM}$ & 4.10 & 4.52 & 5.28 & 0.42 & 0.36 & 0.28 & 9.76 & 12.56 & 18.86 \\
\hline SA at $1.0 \mathrm{mM}$ & 4.08 & 4.36 & 5.68 & 0.45 & 0.38 & 0.32 & 9.07 & 11.47 & 17.75 \\
\hline SA at $1.2 \mathrm{mM}$ & 4.72 & 6.08 & 4.82 & 0.26 & 0.19 & 0.13 & 18.15 & 32.00 & 32.38 \\
\hline Control & 0.2480 & 0.3151 & 0.2223 & 0.0385 & 0.0359 & 0.0302 & 1.1902 & 1.1088 & 1.3621 \\
\hline $\mathrm{CD}(p=0.05)$ & $0.7296^{*}$ & 0.9268 & 0.6539 & 0.1131 & 0.1057 & 0.0889 & 3.5011 & 3.2617 & 4.0066 \\
\hline
\end{tabular}

*: Non significant 
in TSS value. Upto 14 DAS, it was found minimum (4.52 and $4.36{ }^{\circ}$ Brix) under these treatments which later on increased (5.28 and $5.68^{\circ}$ Brix) at 21 DAS. Similarly, drop of titrable acidity was considerably slow under these treatments which resulted in low TSS: acid ratio even at 21 DAS. Aghdam et al., 2010 reported that MeSA at $32 \mu 11^{-1}$ maintained a lower TSS content of Kiwi fruits at cold storage. Kamal Kant et al. (2013) found higher titrable acidity of tomato fruits treated with SA at $0.75 \mathrm{mM}$. Accumulation of TSS and drop of titrable acidity was found slow in SA treated fruits probably due to slowing down of respiration and metabolic activity, hence retarding the ripening process of fruits. Low TSS: acid ratio of fruits treated with SA at 1-1.2 $\mathrm{mM}$ signified that these treatments has potential anti ripening effect (Asghari and Aghdam, 2010).

\subsection{Total sugar and reducing sugar}

Present study showed that fruits at control or treated with SA at lower concentration $(0.2-0.8 \mathrm{mM})$ had accumulation of total sugar upto 14 DAS and afterward reduced at 21 DAS, whereas reducing sugar consistently reduced through the period of storage (Table 3). Fruits treated with SA at 1-1.2 $\mathrm{mM}$ caused delayed accumulation of total sugar with slow decline of reducing sugar. Aghdam et al. (2010) proposed that MeSA reduced ethylene production which may result to decrease sucrose-phosphate synthase activity leading to delay in sucrose synthesis.

\subsection{Ascorbic acid}

Tomato fruits are rich in ascorbic acid. The ascorbic acid content of ripe tomato fruits ranger from $15 \mathrm{mg}$ to $23 \mathrm{mg} 100$ $\mathrm{g}^{-1}$ (Sanchez-Moreno et al., 2006). Preservation of ascorbic acid during storage is a difficult task since it undergoes oxidation (Cantwell et al., 2009). A decrease of ascorbic acid content of fruits indicate senescence (Sammi and Masud, 2007). In our study, it has been observed that fruit vitamin C content reduced with increase in storage time. Fruits at control recorded minimum ascorbic acid content $\left(11.27 \mathrm{mg} 100 \mathrm{~g} \mathrm{~g}^{-1}\right)$ at 21 DAS (Table 3). Gharezi et al. (2012) also had similar kind of observation, where fruits got consistent decrease in ascorbic acid content and fruits at control showed minimum vitamin $\mathrm{C}$

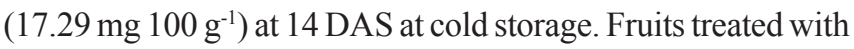
SA showed significantly slow drop in ascorbic acid content. $\mathrm{SA}$ at $1.2 \mathrm{mM}$ caused maximum retention of ascorbic acid (16.43 mg $100 \mathrm{~g}^{-1}$ ) at 21 DAS. Renhua et al. (2008) reported that application of SA was found to be effective in reducing the rate of respiration and ethylene production and maintaining higher amount of ascorbic acid.

Table 3: Effect of selected post-harvest treatments on total sugar, reducing sugar and ascorbic acid content of tomato fruits under refrigerated storage

\begin{tabular}{|c|c|c|c|c|c|c|c|c|c|}
\hline \multirow[t]{2}{*}{ Treatments } & \multicolumn{3}{|c|}{ Total sugar (\%) } & \multicolumn{3}{|c|}{ Reducing sugar (\%) } & \multicolumn{3}{|c|}{ Ascorbic acid (mg $\left.100 \mathrm{~g}^{-1}\right)$} \\
\hline & $7 \mathrm{DAS}$ & 14 DAS & $21 \mathrm{DAS}$ & 7 DAS & 14 DAS & $21 \mathrm{DAS}$ & 7 DAS & 14 DAS & $21 \mathrm{DAS}$ \\
\hline $\mathrm{SA}$ at $0.2 \mathrm{mM}$ & 4.72 & 4.86 & 4.11 & 3.28 & 2.94 & 1.62 & 18.33 & 14.54 & 13.12 \\
\hline $\mathrm{SA}$ at $0.2 \mathrm{mM}$ & 4.68 & 4.70 & 4.23 & 3.24 & 3.01 & 1.68 & 19.59 & 15.17 & 13.64 \\
\hline SA at $0.4 \mathrm{mM}$ & 4.60 & 4.68 & 4.38 & 3.35 & 3.18 & 1.83 & 19.96 & 16.08 & 13.90 \\
\hline $\mathrm{SA}$ at $0.6 \mathrm{mM}$ & 4.55 & 4.65 & 4.46 & 3.59 & 3.31 & 1.95 & 21.54 & 17.96 & 15.80 \\
\hline $\mathrm{SA}$ at $0.8 \mathrm{mM}$ & 4.25 & 4.36 & 4.52 & 3.62 & 3.36 & 1.98 & 21.89 & 18.33 & 16.27 \\
\hline $\mathrm{SA}$ at $1.0 \mathrm{mM}$ & 3.87 & 4.21 & 4.58 & 3.64 & 3.38 & 2.11 & 23.12 & 18.74 & 16.43 \\
\hline $\mathrm{SA}$ at $1.2 \mathrm{mM}$ & 5.02 & 5.42 & 4.02 & 3.12 & 2.14 & 1.39 & 17.96 & 13.90 & 11.27 \\
\hline Control & 0.1446 & 0.1746 & 0.1311 & 0.1274 & 0.1168 & 0.1453 & 0.6963 & 0.5021 & 0.5649 \\
\hline $\mathrm{CD}(p=0.05)$ & 0.4255 & 0.5135 & 0.3857 & 0.3747 & 0.3436 & 0.4273 & 2.0482 & 1.4769 & 1.6618 \\
\hline
\end{tabular}

\subsection{Carotenoids and lycopene}

In the present study, it was observed that carotenoids and lycopene content increased considerably during the period of storage. It was found that fruits at control had carotenoids content of $33.56 \mu \mathrm{g} \mathrm{g}^{-1}$ with $22.43 \mu \mathrm{g} \mathrm{g}^{-1}$ of lycopene (Table 4). Gharezi et al. (2012) reported that cold stored tomato fruits got consistent increase in lycopene content and was scored maximum $\left(4.913 \mathrm{mg} 100 \mathrm{~g}^{-1}\right)$ at $14 \mathrm{DAS}$. It was recorded in the present study, that accumulation of carotenoids and lycopene was slow in case of the fruits treated with SA at relatively higher concentration. At $21 \mathrm{DAS}$, carotenoids and lycopene content was found minimum (21.08 and $12.70 \mu \mathrm{g}$ $\mathrm{g}^{-1}$ ) in case of the fruits treated with SA at $1.2 \mathrm{mM}$. Ding et al. (2002) observed minimum fruit colour $(13.74 \pm 10.80)$ in case of treatment with MeSA at $0.5 \mathrm{mM}$. Pila et al. (2010) found that tomato fruits had low carotenoids and lycopene accumulation ( 29.35 and $28.57 \mu \mathrm{g} \mathrm{g}^{-1}$ ) during storage when treated with SA at $0.4 \mathrm{mM}$.

\subsection{Chilling injury}

Determination of chilling injury is of utmost important while storing of fruits at refrigerated condition as it is related to fruit quality, marketability, disease incidence and overall shelf life 


\begin{tabular}{|c|c|c|c|c|c|c|}
\hline \multicolumn{7}{|c|}{$\begin{array}{l}\text { Table 4: Effect of selected post-harvest treatments on carotenoids } \\
\text { and lycopene content of tomato fruits under refrigerated storage }\end{array}$} \\
\hline \multirow{2}{*}{$\begin{array}{l}\text { Treat- } \\
\text { ments }\end{array}$} & \multicolumn{3}{|c|}{ Carotenoids $\left(\mu \mathrm{g} \mathrm{g}^{-1}\right)$} & \multicolumn{3}{|c|}{ Lycopene $\left(\mu \mathrm{g} \mathrm{g}^{-1}\right)$} \\
\hline & $\begin{array}{c}7 \\
\text { DAS }\end{array}$ & $\begin{array}{c}14 \\
\text { DAS }\end{array}$ & $\begin{array}{c}21 \\
\text { DAS }\end{array}$ & $\begin{array}{c}7 \\
\text { DAS }\end{array}$ & $\begin{array}{c}14 \\
\text { DAS }\end{array}$ & $\begin{array}{c}21 \\
\text { DAS }\end{array}$ \\
\hline $\begin{array}{l}\text { SA at } \\
0.2 \mathrm{mM}\end{array}$ & 7.60 & 14.12 & 32.40 & 7.50 & 12.61 & 21.53 \\
\hline $\begin{array}{l}\text { SA at } \\
0.2 \mathrm{mM}\end{array}$ & 7.20 & 12.64 & 29.16 & 6.82 & 10.05 & 19.03 \\
\hline $\begin{array}{l}\text { SA at } \\
0.4 \mathrm{mM}\end{array}$ & 6.40 & 10.83 & 27.20 & 6.58 & 9.89 & 17.97 \\
\hline $\begin{array}{l}\text { SA at } \\
0.6 \mathrm{mM}\end{array}$ & 6.04 & 9.96 & 26.68 & 5.47 & 9.61 & 16.78 \\
\hline $\begin{array}{l}\text { SA at } \\
0.8 \mathrm{mM}\end{array}$ & 5.82 & 9.80 & 24.08 & 5.30 & 9.27 & 15.04 \\
\hline $\begin{array}{l}\text { SA at } \\
1.0 \mathrm{mM}\end{array}$ & 5.20 & 6.92 & 21.08 & 5.09 & 6.55 & 12.70 \\
\hline $\begin{array}{l}\text { SA at } \\
1.2 \mathrm{mM}\end{array}$ & 8.40 & 14.32 & 33.56 & 7.80 & 14.51 & 22.43 \\
\hline Control & 0.2790 & 0.5225 & 1.0236 & 0.4122 & 0.4952 & 0.8561 \\
\hline $\begin{array}{l}\mathrm{CD} \\
(p=0.05)\end{array}$ & 0.8206 & 1.5369 & 3.0111 & 1.2126 & 1.4568 & 2.5182 \\
\hline
\end{tabular}

of the stored fruit. Present study showed that tomato fruits got maximum CII (4.98) at control, whereas CII was recorded considerably low (1.44-2.88) in case of fruits treated with SA at 1-1.2 mM (Plate 1). Ding et al. (2002) reported that tomato fruits got maximum chilling injury at control compared with the fruits treated with MeSA at $0.5 \mathrm{mM}$. Aghdam et al. (2012) found that maximum CII ( $>4.5)$ in case of fruits at control compared with fruits treated with SA at $1.0(\mathrm{CII}>2.0)$
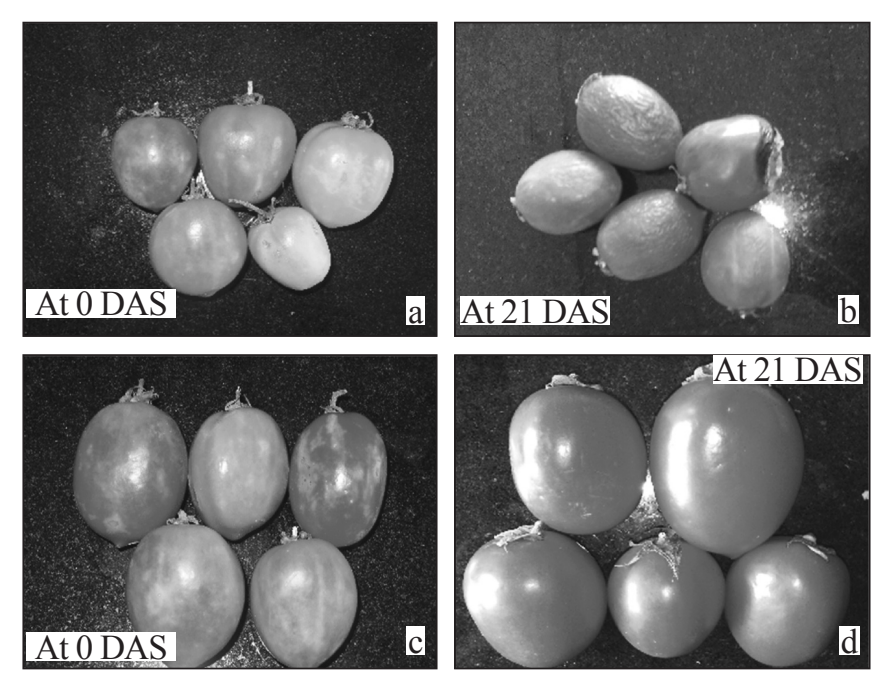

Plate 1: Tomato fruits at refrigerated storage [ (a) and (b) control at 0 and $21 \mathrm{DAS}$; (c) and (d) treated with SA at 1.2 $\mathrm{mM}$ at 0 and $21 \mathrm{DAS}]$ and $2.0 \mathrm{mM}(\mathrm{CII}<1.0)$. Chilling injury affects primarily the cell membrane with changes in the fatty acid composition of phospholipids (Lurie et al., 1987; Stanley and Parkin, 1991; Mirdehghan et al., 2007). Membrane damage caused electrolyte leakage (Aghdam et al., 2012) and intensity of that reflects CII development phase and degree in tomato fruit (Zhao et al., 2009). Role of SA in maintaining membrane integrity has been reported for loquat (Cai et al., 2006) and pomegranate (Sayyari et al., 2011) fruits. Aghdam et al. (2012) reported that salicylic acid treatment effectively alleviated symptoms and severity of CI; and possibly maintained membrane integrity, owing to reduced electrolyte leakage. Wang et al. (2006) found similar results in case of peach fruit where alleviation of CI was achieved at $1 \mathrm{mM}$ but failed at $0.7 \mathrm{mM}$ or lower SA concentrations.

\subsection{Shelf life}

Present study showed that fruits at control had minimum shelf life (24 days) when stored at refrigerated $\left(4-5^{\circ} \mathrm{C}\right)$ condition. Okolie and Sanni (2012) reported of 28 days of storage of tomato under cold storage. SA treated fruits had better shelf life (ranged between 25.25-32.75 days) than control. Shelf life was found maximum (32.75 days) in case of the fruits treated with SA at $1.2 \mathrm{mM}$ (Plate 1). It was reported that SA had significant influence on respiration, ethylene biosynthesis, fruit ripening and had potentiality of controlling post harvest fruit decay (Asghari and Aghdam, 2010; Babalar et al., 2007) which may be the reason for having more shelf life under SA treated fruits. Kamal Kant et al. (2013) also found that the shelf life of tomato fruits has been increased for 7 days more than fruits at control when treated with SA at $0.75 \mathrm{mM}$.

\section{Conclusion}

The results of the present experiment showed that SA at 1.0$1.2 \mathrm{mM}$ maybe the effective post harvest treatment to extend shelf life while maintaining the physico-chemical attributes of tomato cv. Samrudhi under refrigerated storage.

\section{References}

A.O.A.C., 1990. Official Methods of the Analysis (15 ${ }^{\text {th }}$ Edn.). Association of Analytical Chemists, Washington D.C., USA.

Aghdam, M.S., Asghari, M.R., Moradbeygi, H., Mohammadkhani, N., Mohayeji, M., Fard, J.R., 2012. Effect of post harvest salicylic acid treatment on reducing chilling injury in tomato fruit. Romanian Biotechnological Letters 17, 7466-7473.

Aghdam, M.S., Motallebiazar, Y., Mostofi, Y., Moghaddam, J.F., Ghasemneghad, M., 2010. Effect of Me SA vapour treatment on the postharvest quality of Hayward kiwi fruit. Acta Horticulturae 877, 743-748. 
Ahmad, S., Singh, Z., Khan, A.S., Iqbal, Z., 2013. Pre harvest application of salicylic acid maintain the rind textural properties and reduce fruit rot and chilling injury of sweet orange during cold storage. Pakistan Journal of Agricultural Science 50, 559-569.

Anonymous, 2014a. Food and Agriculture Organisation of the United Nation Database. Available from http://faostat. fao.org. Accessed in June, 2014).

Anonymous, 2014b. Indian Horticulture Database 2013. National Horticulture Board, Ministry of Agriculture, Govt. of India, 2-289.

Asghari, M., Aghdam, M.S., 2010. Impact of salicyclic acid on post harvest physiology of horticultural crops. Trends in Food Science and Technology 21, 501-509.

Aworh, O.C., Olorunda, A.O., 1981. Towards reducing post-harvest losses of perishable fruits and vegetables in Nigeria: From Food Deficiency to Food Sufficiency in the '80s. In: National Conference in Agriculture, Rivers State University of Science and Technology, Port Harcourt, 81-92.

Babalar, M., Asghari, M., Talaei, A., Khosroshahi, A., 2007. Effect of pre and post harvest salicylic acid treatment on ethylene production, Fungal decay and overall quality of selva strawberry fruit. Food Chemistry 105, 449-453.

Barman, K., Asrey, R., 2014. Salicylic acid pre-treatment alleviates chilling injury, preserves bioactive compounds and enhances shelf life of mango fruit during cold storage. Journal of Scientific and Industrial Research 73, 713-718.

Bhowmik, S.R., Pan, J.C., 1992. Shelf life of mature green tomatoes stored in controlled atmosphere and high humidity. Journal of Food Science 57, 948-953.

Cai, C., Li, X., Chen, K., 2006. Acetyl salicylic acid alleviates chilling injury of postharvest loquat (Eriobotrya japonica Lindl.) fruit. European Food Research and Technology 223, 533-539.

Cantwell, M., Nie, X., Hong, G., 2009. Impact of storage condition on grape tomato quality. In: $6^{\text {th }}$ ISHS Post Harvest Symposium, Antalya, Turkey. Available from http:/ucce.ucdavis.edu/files/datastore/234-1531.pdf.

Ding, C.K., Wang, C.Y., Gross, K.C., Smith, D.L., 2002. Jasmonate and salicylate induce the expression of pathogenesis-related-protein genes and disease resistance to chilling injury in tomato fruit. Planta 214, 895-901.

Gharezi, M., Joshi, N., Sadeghian, E., 2012. Effect of post harvest treatment on stored cherry tomatoes. Journal of Nutrition and Food Science 2, 157.

Gomez, K.A., Gomez, A.A., 1984. Statistical Procedure for Agricultural Research ( $2^{\text {nd }}$ Edn.). John Willey and Sons., $8-13$.
Gopalakrishnan, T.R., 2007. Vegetable crops, Vol. 4, Hort. Sc. Series. New India Publishing Agency, New Delhi, India, 87-97.

Kamal Kant, Arora, A., Singh, V.P., Kumar, R., 2013. Effect of exogenous salicylic acid and oxalic acid application on post harvest shelf life of tomato (Solanum lycopersicon L.). Indian Journal of Plant Physiology 18, 15-21.

Lurie, S., Sonego, L., Ben-Arie, R., 1987. Permeability, microviscosity and chemical changes in the plasma membrane during storage of apple fruit. Scientia Horticulturae 32, 73-83.

Mandal, D., Lalremruata, Hazarika, T.K., Nautiyal, B.P., 2015. Effect of Post-harvest Treatments on Quality and Shelf Life of Pineapple (Ananas comosus [L.] Merr. 'Giant Kew') Fruits at Ambient Storage Condition. International Journal of Bio-resource and Stress Management 6(4), 490-496.

Mandal, D., Lalrindika, E., Hazarika, T.K., Nautiyal, B.P., 2016. Post harvest application of salicylic acid enhanced shelf life and maintained quality of banana cv. 'Grand Naine' at ambient storage. The Bioscan 11(1), 265-270. Manthe, B., Schulz, M., Schnabl, H., 1992. Effect of salicylic acid on growth and stomatal movements of Vicia faba L.: evidence for salicylic acid metabolization. Journal of Chemical Ecology 18, 1525-1539.

Mirdehghan, S.H., Rahemi, M., Martinez-Romero, D., Guillen, F., Valverde, J.M., Zapata, P.J., Serrano, M., Valero, D., 2007. Reduction of pomegranate chilling injury during storage after heat treatment: role of polyamines. Postharvest Biology and Technology 44, 19-25.

Mohammed, M., Wickham, L.D., 1997. Occurrence of chilling injury in Golden Apple (Spondias dulcis, Sonn.) fruits. Journal of Food Quality 20, 91-104.

Moneruzzaman, K.M., Hossain, A.B.M.S., Sani, W., Saifuddin, M., Alenazi, M., 2009. Effect of harvesting and storage conditions on the post harvest quality of tomato (Lycopersicon esculentum Mill.) cv. Roma VF. Australian Journal of Crop Science 3,113-121.

Okolie, N.P., Sanni, T.E., 2012. Effect of postharvest treatments on quality of whole tomatoes. African Journal of Food Science 6, 70-76.

Pila, N., Neeta, B.G., Rao, T.V.R., 2010. Effect of Post harvest treatments on physico chemical characteristics and shelf life of tomato (Lycopersicon eseulentum Mill.). Fruits during storage. American-Eurasian Journal of Agricultural and Environmental Sciences 9, 470-479.

Ranganna, S., 1997. Handbook of Analysis and Quality Control for Fruits and Vegetable Products. Tata McGraw Hill Publishing Co. Ltd., New Delhi, 875-886.

Rao, A., Agarwal, S., 1999. Role of lycopene as antioxidant 
carotenoid in the prevention of chronic diseases: a review. Nutrition Research 19, 305-323.

Renhua, H., Renxue, X., Yunmel, L., Liming, H., Yongjie, X., 2008. Effect of pre harvest salicylic acid spray treatment on post harvest antioxidant in the pulp and peel of 'Cara cara' navel orange (Citrus sinensis L. Osbeck). Journal of the Science of Food and Agriculture 88, 229-236.

Sadasivam, S., Manickam, A., 1997. Biochemical methods. New Age Int. (P) Ltd., New Delhi, India, 187.

Sammi, S., Masud, T., 2007. Effect of different packaging systems on storage life and quality of tomato (Lycopersicon esculentum var. 'Rio Grande') during different ripening stages. Internet Journal of Food Safety 9, 37-44.

Sanchez-Moreno, C., Plaza, L., De Ancos, B., Cano, M.P., 2006. Impact of high pressure and traditional thermal processing of tomato puree on carotenoids, vitamin C and anti oxidant activity. Journal of the Science of Food and Agriculture 86, 171-179.

Sayyari, M., Castillo, S., Valero, D., Diaz-Mula, H.M., Serrano, M., 2011. Acetyl salicylic acid alleviates chilling injury and maintains nutritive and bioactive compounds and antioxidant activity during postharvest storage of pomegranates. Postharvest Biology and Technology 60, 136-142.

Stanley, D.W., Parkin, K.L., 1991. Biological membrane deterioration and associated quality losses in food tissues. Critical Reviews in Food Science and Nutrition 30, 487-553.

Tareen, M.J., Abbasi, N.A., Hafiz, I.A., 2012. Post harvest application of salicylic acid enhanced anti oxidant enzyme activity and maintained quality of peach $\mathrm{cv}$. 'Flordaking' during storage. Scientia Horticulturae 142, 221-228.

Wang, L., Chen, S., Kong, W., Li, S., Archbold, D.D., 2006. Salicylic acid pre treatment alleviates chilling injury and affects the antioxidant system and heat stock protein of peaches during cold storage. Postharvest Biology and Technology, 41, 244-251.

Zhao, D.Y., Shen, L., Fan, B., Liu, K.L., Yu, M.M., Zheng, Y., Ding, Y., Sheng, J.P., 2009. Physiological and genetic properties of tomato fruits from 2 cultivars differing in chilling tolerance at cold storage. Food Chemistry 74, 348-352.

Zheng, Y., Zhang, Q., 2004. Effects of polyamines and salicylic acid post harvest storage of 'Ponkan' mandarin. Acta Horticulturae 632, 317-320.

Znidarcic, D., Pozrl, T., 2006. Comparative study of quality changes in tomato cv. 'Malike' (Lycopersicon esculentum Mill.) whilst stored at different temperatures. Acta Agriculturae Slovenica 87, 235-243. 